\title{
The Effect of the Think Talk Write (TTW) Learning Model on the Students' Ability to Write Commercial Letters in High School Students Grade XI
}

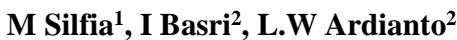 \\ \{megga.s@yahoo.com $\left.{ }^{1}\right\}$ \\ 1,2 Master Program Student, Faculty of Language and Art, Universitas Negeri Padang, Padang, \\ Indonesia
}

\begin{abstract}
The purpose of this study was to describe the "The Effects of the Think Talk Write (TTW) Learning Model on the Students' Ability to Write Commercial Letters in Grade XI at SMA Negeri 1 V Koto Kampung Dalam". The research method used is an experiment. The research subjects were grade XI students of SMA Negeri $1 \mathrm{~V}$ Koto Kampung Dalam. The results of this study indicate that first, the ability to write a commercial letter using the think talk write learning model by grade XI Students of SMA Negeri 1 V Koto Kampung Dalam with an average value of 83.82 is included in the excellent category. Second, the ability to write a commercial letter by using a conventional learning model by grade XI students of SMA Negeri 1 V Koto Kampung Dalam with an average value of 67.29 included in the sufficient category. Third, Based on the results of the test results obtained $t_{\text {count }}>t_{\text {table }}$ is 6.06 $>1.66$. So $h_{o}$ is rejected and $h_{a}$ is accepted. Thus it can be concluded that there is the influence effects of the Think Talk Write (TTW) learning model on the students' ability to write commercial letters in grade XI at SMA Negeri 1 V Koto Kampung Dalam.
\end{abstract}

Keywords: experiment, learning model, think talk write (TTW)

\section{Introduction}

Education, in essence, is a conscious effort to prepare students through guidance and teaching activities. In teaching Indonesian four language skills must be considered. These skills include the ability to listen, speak, read, and write. If learning is done by linking the four aspects, the learning activities will be more focused so that student learning activeness increases in the end.

As one aspect of language skills, writing is not a stranger in human life. However, in reality, not everyone can put all their opinions, ideas or contents into complex writing. Based on this, it is no exaggeration to say writing is a complex ability that demands several abilities and skills.

In the school environment, Indonesian language teaching has been established firmly and clearly. However, the implementation often fails in achieving the stated goals. Failure to achieve these goals can be caused by the learning model factors that the teacher uses in the classroom are not following the situations and conditions that support the learning process, so that the impact on learning outcomes. 
Seeing some problems in students in the learning process, problems that arise, namely the ability of students to write commercial letters have not reached a satisfactory level. There are still many students who do not understand how to write trade letters properly and correctly. From the phenomenon that has been conveyed, it can be assumed that the learning model used by the teacher so far needs a variety of learning models. This is where the teacher is required to use a learning model that can improve the condition.

Given the problems that exist, there needs to be a renewal effort to see the ability to write commercial letters of high school students, namely by learning using the Think Talk Write (TTW) learning model. [1] states that learning that can spur students to be more active in teaching and learning activities is the Think Talk Write (TTW) model. The Think Talk Write (TTW) model can focus the learning process into (student-centered) in this case the sued students are more active than the teacher.

Think Talk Write (TTW) learning model, [2], [3], [4] states that activities that can be carried out to develop students' ability to understand concepts and communication are by applying Think Talk Write learning. First, think means to think. In the big Indonesian dictionary, thinking means using reason to consider and decide something. Thinking is a mental activity to be able to formulate an understanding, synthesize, and draw conclusions. Based on the above meanings, thinking (think) is a mental activity carried out to make decisions and draw conclusions after going through the process of considering. Second, talk means talking. In the Big Indonesian Dictionary, talk means to consider, thoughts, and opinions. At the talking stage, students work with their groups aiming to build mutual understanding and knowledge through interaction and conversation between individuals in the group. Third, write means writing. In the Indonesian dictionary, writing is making letters (numbers, etc.) with pens (pencils, chalks, and so on). Writing activities will help students make connections and also allow teachers to see the development of students' concepts. Writing means helping to realize one of the learning objectives, namely students' understanding of the material he is learning.

This Think Talk Write (TTW) model has been applied by [5], [6], [7], [8], [9], [10], [11], [12], [13], [14], [15], [16] from the study the Think Talk Write (TTW) model has a significant effect on the results and student learning activities. Based on the explanation, it can also be concluded that the Think Talk Write (TTW) model is well used to train students' thinking well. For this reason, the Think Talk Write (TTW) learning model emphasizes increasing students' reasoning power, students' critical power, students' imagination, and analysis of problems.

Thus the authors are interested in researching with the title "The Effects of the Think Talk Write (TTW) Learning Model on the Students' Ability to Write Commercial Letters in Grade XI at SMA Negeri 1 V Koto Kampung Dalam". The limitation of the problem taken is focused on the influence of Think Talk Write (TTW) learning model on the ability to write a commercial letter in grade XI at SMA Negeri 1 V Koto Kampung Dalam.

\section{Method}

Stated [17], "the research method is the method used by researchers in collecting research data". The method used in this study is the research method. This study aims to study "The The Effects of the Think Talk Write (TTW) Learning Model on the Students' Ability to Write Commercial Letters in Grade XI at SMA Negeri 1 V Koto Kampung Dalam".

This research was conducted at SMA Negeri 1 V Koto Kampung Dalam, Pariaman. This research is an experimental study, so this sample is divided into two groups. The first group 
was XI-IPA2 class as an experimental class with 35 students and the second group XI-IPA1 class as a control class with 35 students. This study uses an instrument consisting of writing a commercial letter in written form. With the instrument data obtained for variables X1 and X2.

Table 1. Research Design Posttest-Only Control

\begin{tabular}{|l|l|l|}
\hline Class & Treatment & Post-test \\
\hline XI-IPA 2 $\left(\mathrm{X}_{\mathrm{I}}\right)$ & $\mathrm{X}$ & $\mathrm{T}_{1}$ \\
\hline XI-IPA 1 $\left(\mathrm{X}_{2}\right)$ & - & $\mathrm{T}_{2}$ \\
\hline
\end{tabular}

\section{Information:}

$\mathrm{XI}$ and X2: Classes randomly selected for class experiment and control class

$\mathrm{X}$ : Experimental treatment

$\mathrm{T} 1$ and T2: Influence after therapy

Table 2. Learning Steps for the Experimental and Control

\begin{tabular}{|c|c|c|}
\hline $\begin{array}{l}\text { Experimentation Class } \\
\text { (Model Think Talk Write) }\end{array}$ & $\begin{array}{l}\text { Control class } \\
\text { (Conventional Model) }\end{array}$ & $\begin{array}{l}\text { Time } \\
2 \times 45\end{array}$ \\
\hline $\begin{array}{l}\text { Initial activity } \\
\text { 1. Pray } \\
\text { 2. The teacher creates a conducive } \\
\text { learning atmosphere and } \\
\text { focuses attention on students } \\
\text { 3. Give praise. Giving praise can } \\
\text { increase morale and motivate } \\
\text { students. }\end{array}$ & $\begin{array}{l}\text { Initial activity } \\
\text { 1. Pray } \\
\text { 2. The teacher creates a conducive } \\
\text { learning atmosphere and focuses } \\
\text { attention on students }\end{array}$ & 10 Minute \\
\hline $\begin{array}{l}\text { Core activities: } \\
\text { 1. The teacher divides the group, } \\
\text { one group consists of } 5 \text { people } \\
\text { 2. The teacher divides the reading } \\
\text { text in the form of a Student } \\
\text { Discussion Sheet (LDS) which } \\
\text { contains the problem situation } \\
\text { and the instructions and } \\
\text { procedures for } \\
\text { implementation } \\
\text { 3. Students read the text and make } \\
\text { notes of the reading results } \\
\text { individually to be taken to the } \\
\text { discussion forum (think) } \\
\text { 4. Students interact } \\
\text { collaborate with their group } \\
\text { friends to discuss the contents } \\
\text { of the notes (talk) } \\
\text { The teacher acts as a mediator } \\
\text { of the learning environment, }\end{array}$ & $\begin{array}{l}\text { Core activities: } \\
\text { 1. Explain the trade letter } \\
\text { 2. Explain how to write a commercial } \\
\text { letter } \\
\text { 3. Invite students to ask questions for } \\
\text { those who do not understand } \\
\text { 4. Asking students to work on writing } \\
\text { commercial letters } \\
\text { 5. Asking students to show their } \\
\text { work to the teacher }\end{array}$ & 60 Minute \\
\hline
\end{tabular}




\begin{tabular}{|l|l|l|}
\hline $\begin{array}{l}\text { students construct their own } \\
\text { knowledge as a result of } \\
\text { collaboration (write). }\end{array}$ & \\
\hline $\begin{array}{l}\text { End activities: } \\
\begin{array}{l}\text { 1. The teacher instructs students to } \\
\text { make a commercial letter } \\
\text { 2. Pray to end learning }\end{array}\end{array}$ & $\begin{array}{l}\text { End activities: } \\
\text { 1. The teacher instructs students to } \\
\text { make a commercial letter } \\
\text { 2. The teacher closes the learning by } \\
\text { saying greetings }\end{array}$ & 20 Minute \\
\hline
\end{tabular}

Table 3. Assessed Aspects

\begin{tabular}{|c|c|c|c|}
\hline No & Rated aspect & $\begin{array}{c}\text { Indicators and basis for } \\
\text { assessment }\end{array}$ & Score \\
\hline 1. & Seller and Buyer Identity & $\begin{array}{l}\text { 1. Identity of both parties is } \\
\text { complete } \\
\text { 2. The identity of both parties is } \\
\text { incomplete } \\
\text { 3. The identity of both parties is } \\
\text { incomplete }\end{array}$ & $\begin{array}{l}3 \\
2 \\
1\end{array}$ \\
\hline 2. & $\begin{array}{l}\text { Articles (rights and } \\
\text { obligations of sellers and } \\
\text { buyers) }\end{array}$ & $\begin{array}{l}\text { 1. Article written in full } \\
\text { 2. Article written is incomplete } \\
\text { 3. Article written is incomplete }\end{array}$ & $\begin{array}{l}3 \\
2 \\
1\end{array}$ \\
\hline 3. & Place and date of agreement & $\begin{array}{l}\text { 1. Place and date of complete } \\
\text { agreement } \\
\text { 2. The place and date of the } \\
\text { agreement are incomplete } \\
\text { 3. The place and date of the } \\
\text { agreement are incomplete }\end{array}$ & $\begin{array}{l}3 \\
2 \\
1\end{array}$ \\
\hline 4. & $\begin{array}{l}\text { Seller-buyer names and } \\
\text { signatures }\end{array}$ & $\begin{array}{l}\text { 1. Complete seller-buyer name and } \\
\text { signature } \\
\text { 2. The seller's name and signature are } \\
\text { incomplete } \\
\text { 3. Seller-buyer names and signatures } \\
\text { are incomplete }\end{array}$ & $\begin{array}{l}3 \\
2 \\
1\end{array}$ \\
\hline 5. & $\begin{array}{l}\text { Names and signatures of } \\
\text { witnesses }\end{array}$ & $\begin{array}{l}\text { 1. Full names and signatures of } \\
\text { witnesses } \\
\text { 2. The names and signatures of } \\
\text { witnesses are incomplete } \\
\text { 3. The names and signatures of } \\
\text { witnesses are incomplete }\end{array}$ & $\begin{array}{l}3 \\
2 \\
1\end{array}$ \\
\hline 6. & $\begin{array}{l}\text { Spelling accuracy, } \\
\text { punctuation, and use of } \\
\text { capital letters. }\end{array}$ & $\begin{array}{l}\text { 1. There are no errors } \\
\text { 2. There are } 5 \text { to } 10 \text { errors } \\
\text { 3. There are more than } 10 \text { errors }\end{array}$ & $\begin{array}{l}3 \\
2 \\
1\end{array}$ \\
\hline \multicolumn{3}{|r|}{ Total } & 18 \\
\hline
\end{tabular}


Value $=\frac{\text { Score obtained }}{\text { Maximum score }} \times 100$

Tabel 4. Comparison Criteria for Value of Student Learning Outcomes

\begin{tabular}{|c|c|c|}
\hline No. & Value Category & Value \\
\hline 1. & Very good & $80-100$ \\
2. & Well & $70-79$ \\
3. & Enough & $60-69$ \\
4. & Less & $50-59$ \\
5. & Very less & $0-49$ \\
\hline
\end{tabular}

\section{Result and Discussion}

After the research was conducted by giving tests in the form of essays to class grade XI Students of SMA Negeri 1 V Koto Kampung Dalam, 35 experimental class students and 35 control class students, all the results of the completed tests were collected for analysis.

After knowing the raw score of each student, the score is summed to find the mean. To calculate the mean, use the following formula:

Average experimental class score

$M=\frac{\sum x}{N}$

$M=\frac{2916,51}{35}$

$M=83,32$

Based on the above discussion, it can be seen that the average value obtained by grade XI Students of SMA Negeri $1 \mathrm{~V}$ Koto Kampung Dalam in the ability to write a commercial letter using the think talk write model is 67.29.

\subsection{Homogeneity Test}

Data homogeneity testing is done to find out the sample used in the study whether homogeneous or not and whether the sample used in the study can represent the entire population, the calculation is as follows:

$$
\begin{array}{llll}
X 1=83,32 & \mathrm{SD}=13,13 & \mathrm{SD}^{2}=172,510 & \mathrm{~N}=35 \\
\mathrm{X} 2=67,29 & \mathrm{SD}=12,90 & \mathrm{SD}^{2}=116.599 & \mathrm{~N}=35
\end{array}
$$

Then,

$$
\begin{aligned}
& F_{\text {count }}=\frac{\text { Varian the biggest }}{\text { Varian smallest }}=\frac{172,510}{116,559}=1,48 \\
& F_{\text {count }}=\frac{d k \text { numerator }}{\text { dk denominator }}=\frac{35-1}{35-1}
\end{aligned}
$$

Based on the numerator number 35-1 and the denominator 35-1 = 34 and in $\mathrm{f}_{\text {table }}$ that is 1.77. So, $\mathrm{f}_{\text {count }}<\mathrm{f}_{\text {table }}$ is $1.48<1.77$. This proves that the sample comes from a homogeneous group, meaning that the data obtained represents the entire population. 


\subsection{Hypothesis testing}

After calculating the score and the final value for each variable, then the effect of learning is sought by using the think talk write learning model for writing trade letters. In this study the researcher conducted a comparison between the results of the ability to write a commercial letter with the think talk writing learning model and the ability to write writing a commercial letter with a conventional model, for which the authors used the formula:

$\mathrm{T}_{\text {count } g}=\frac{x_{1}+x_{2}}{\sqrt[s]{\frac{1}{n 1}+\frac{1}{n 2}}} \quad$ with value, $\mathrm{S}^{2}=\frac{\left(n_{1}-1\right) S_{1}^{2}+\left(n_{2-1}\right) S_{2}^{2}}{\left(n_{1}+n_{2}\right)-2}$

$\mathrm{X}_{1}=83,32$

$X_{2}=67,29$

$n_{1}=35$

$n_{2}=35$

$S_{1}^{2}=172,510$

$S_{2}^{2}=116.599$

Then the above values are transformed into the following formula:

$S^{2}=\frac{\left(n_{1}-1\right) S_{1}^{2}+\left(n_{2-1}\right) S_{2}^{2}}{\left(n_{1}+n_{2}\right)-2}$

$\mathrm{S}^{2}=\frac{(35-1) 172,510+(35-1) 116.599}{(35+35)-2}$

$\mathrm{S}^{2}=\frac{5865,34+3963,366}{68}$

$S^{2}=\frac{\sqrt{9828,706}}{68}$

$\mathrm{S}=\sqrt{144,539}$

$\mathrm{S}=12,02$

Then $t_{\text {count }}$ is

$\mathrm{T}_{\text {count }}=\frac{x_{1}-x_{2}}{\sqrt[s]{\frac{1}{n 1}}+\frac{1}{n 2}}$

$\mathrm{T}_{\text {count }}=\frac{83,32-67,29}{\sqrt[12,02]{\frac{1}{35}}+\frac{1}{35}}$

$\mathrm{T}_{\text {count }}=\frac{16,03}{(12,02) \sqrt{0,05}}$

$\mathrm{T}_{\text {count }}=\frac{16,03}{(12,02)(0,22)}$

$\mathrm{T}_{\text {count }}=\frac{150,67}{2,6444}$

$\mathrm{T}_{\text {count }}=6,06$

After the $t$ count is obtained, then it is compared with the value of $t_{\text {table }}$ at the significance level $=0.05$ with $\mathrm{dk}=\mathrm{N} 1+\mathrm{N} 2-2=68$ obtained $\mathrm{t}_{\text {table }}=1.66$ thus $\mathrm{t}_{\text {count }}>\mathrm{t}_{\text {table }}$ is $6.06>1.66$ then $\mathrm{h}_{\mathrm{a}}$ is accepted by the hypothesis reads "the influence effects of the Think Talk Write (TTW) learning model on the students' ability to write commercial letters in grade XI at SMA Negeri 1 V Koto Kampung Dalam". 


\section{Conclusion}

Based on the results of research and data analysis obtained several conclusions as follows. First, the ability to write a commercial letter using the think talk write learning model by grade XI students of SMA Negeri 1 V Koto Kampung Dalam with an average value of 83.82 included in the excellent category. Second, the ability to write a commercial letter by using a conventional learning model by grade XI students of SMA Negeri 1 V Koto Kampung Dalam with an average value of 67.29 included in the sufficient category. Third, Based on the results of the test results obtained $t_{\text {count }}>t_{\text {table }}$ is 6.06 $>1.66$. So $h_{o}$ is rejected and $h_{a}$ is accepted. Thus it can be concluded that there is the influence of the think talk write learning model on the ability to write commercial letters by grade XI students of SMA Negeri 1 V Koto Kampung Dalam.

Based on the results of this study, the suggestions that researchers can give are as follows. First, considering the mean of writing a commercial letter using the think talk write learning model is not maximal, so it is better for Indonesian language subject teachers to improve the quality of the lesson. Second, to improve student learning outcomes, teachers should be able to provide training in writing commercial letters, use of varied books and use of appropriate learning models.

\section{References}

[1] A. Ardiansyah, "Meningkatkan Hasil Belajar Pada Materi Pokok Hidrokarbon Melalui Model Pembelajaran Kooperatif Tipe TTW (Think Talk Write) Bermuatan Karakter Siswa Kelas X-4 SMAN 6 Banjarmasin.” Vol.4, No.1, Jurnal QUANTUM Inovasi Pendidikan Sains, pp. 93-104, 2013.

[2] A. Shoimin, 68 Model Pembelajaran Inovatif dalam Kurikulum 2013. Depok: Ar-ruz Media, 2014.

[3] P. Nurjanah, \& A. S. Rukmi, "Pengaruh Model Pembelajaran Kooperatif Tipe TTW Terhadap Keterampilan Menulis Eksposisi Siswa Kelas V Sekolah Dasar Negeri di Kecamatan Lakarsantri Surabaya."Vol.5, No.2, JPGSD, Jurnal PGSD, pp.486-499, 2017.

[4] Depdiknas, Kamus Besar Bahasa Indonesia. Jakarta: Balai Pustaka, 2007.

[5] Wiyaka \& I. S. Ansori, "Think-Talk-Write (TTW) as a Strategy to Improve Students' Ability in Teaching Writing Descriptive Text: A Case of the Tenth Grade Students of MAN Demak." Vol.4, No.1, Jurnal ETERNAL: English Teaching Journal, pp.80-91, 2013.

[6] N. F. Utami, Budiyono \& B. Usodo, "Eksperimentasi Model Pembelajaran Think Talk Write (TTW) dengan Pendekatan Matematika Realistik (PMR) Terhadap Prestasi Belajar Matematika Ditinjau dari Kemampuan Penalaran matematika dan kreativitas belajar siswa SMP se-kabupaten Wonogiri." Vol.2, No.3, Jurnal elektronik pembelajaran matematika, pp.260-269, 2014.

[7] A. Asy'ari, "Model pembelajaran Think Talk Write (TTW) Berbasis Assesment for Learning (AFL) Melalui Penilaian Teman Sejawat Meningkatkan Kemandirian Belajar Siswa Kelas VIII." Vol. 2, No.2, Math Didactic: Jurnal Pendidikan Matematika, pp 116-126, 2016.

[8] E. Suyanto, "Pembelajaran Matematis dengan Strategi TTW Berbasis Learning Journal untuk Meningkatkan Kemampuan Menulis Matematis.” Journal KREANO: Jurnal Matematika Kreatif-Inovatif 7 (1), pp. 58-65, 2016. 
[9] N.U. Husna, \& E. Surya, "The Effectiveness of Think Talk Write Learning Model in Improving Students Mathematical Communications Skills at Mts Al Jami'yatul Washiyah Tembung." Vol. 34, No.2, International Journal of Science: Basic and Applied Research (IJSBAR), pp.1-12, 2017.

[10] R. Riski, M. Rizal, \& Linawati, "Penerapan Model Pembelajaran Kooperatif Tipe Think Talk Write (TTW) untuk Meningkatkan Hasil Belajar Siswa pada Materi Hubungan Sudut Pusat, Panjang Busur, dan Luas Juring di Kelas VIII C SMP Negeri 9 Palu.” Vol.5, No.2, Jurnal elektronik Pendidikan Matematika Tadulako, pp. 1-16, 2017.

[11] R. Setiawan, I. N. Sujana, \& K. Apgrianto, "The Effect of Think Talk Write Technique on Students Writing Ability." Vol.1, No.1, ELT-Tech Journal, English Language Teaching and Technology Journal, pp.31-39, 2017.

[12] N. M. Sari, "Pengaruh Model Pembelajaran Think Talk Write Terhadap Kemampuan Menulis Puisi oleh Siswa Kelas VIII SMP Swasta Tunas Karya Batang Kuis.” Vol.1, No.2, Jurnal Edukasi Kultura: Jurnal Bahasa, Sastra, dan Budaya, pp.1-9, 2017.

[13] Wirda, D. Setiawan, \& Hidayat, "The Effect of Think Talk Write (TTW) Learning Method on The Creative Thinking Ability of The Students at Primary Scholl (SD)." Vol.5, No.11, British Journal of Education, Published by European Centre for Research Training and Development UK, pp.12-28, 2017.

[14] H. Ambarsari, H. Syarif, \& Refnaldi, "The Effect of Think Talk Write (TTW) Strategy and Students' Reading Habit Toward Students' Writing Ability, Prosiding of the Sixth International Conference on English Language and Teaching Journal ICOELT-6, pp.118-125, 2018.

[15] A. S. Susanto, "The effect of Cooperative Learning Model Think-Talk-Write (TTW) Type on Mathematical Problem-Solving Abilities In terms of Learning Habits." Vol.9, No.1, Jurnal Al-Jabar: Jurnal Pendidikan Matematika, pp.33-44, 2018.

[16] S. Martini, \& E. Nainggolan, "Application of Think Talk Write Model (TTW) to Improve Comunication Ability of Grade XII Students on Biology Learning." International Conference on Mathematics and Science Education (ICMScE), IOP Conf. Series: Journal of Physics: Conf. Series 1157 (2019) 022112, doi:10.1088/17426596/1157/2/022112, pp.1-6, 2019.

[17] S. Arikunto, Prosedur Penelitian Suatu Pendekatan Praktik. Jakarta: Rineka Cipta, 2013. 